\title{
Tudi Kernalegenn, François Prigent, Gilles Richard, Jacqueline Saincliver, eds., Le PSU vu d'en bas: Réseaux sociaux, movement politique, laborato- ries d'idées, années 1950- 1980 (Rennes, France: Presses Universitaires de Rennes, 2009).
}

Le PSU vu d'en bas makes an important contribution to the literature on the twentieth-century European Left. In the whirlwinds of French politics, parties have risen, collapsed and reinvented themselves. To comprehend French politics, indeed to understand France, it is necessary to carefully examine the ebb and flow of various party formations. While more powerful and enduring groups on the Left, like Socialists and Communists, have attracted a fair amount of scholarly scrutiny, less long lasting organizations like the United Socialist Party (PSU) are often relegated to footnotes.

The PSU had a brief lifespan even by French standards. Formally established in April 1960, the remnants of the United Socialist Party officially dissolved the group almost three decades to the day later, in 1990. Despite this short thirty-year existence, the PSU, as this excellent collection of essays illustrates, was a remarkable experiment. Passing through its ranks were numerous activists whose personal political commitment would outlast the party that trained them.

The studies gathered in this volume demonstrate that the importance of the United Socialist Party went beyond the group's electoral weakness or ultimate collapse. A convincing case is made that careful study of the PSU reveals an organization that made any number of contributions to the molding of the French Left. By looking at specific issues, like its support for women's rights, and regional influence, such as in Brittany, this book provides texture and nuance to the discussion of this unique organization. As the subtitle suggests, the PSU was certainly a laboratory for ideas.

With an emphasis on grassroots activity, the PSU was markedly different from their better known leftist rivals. This approach allowed the party to bridge the gap that had existed between the traditional secular, if not anti-clerical, left and radicalized Catholic activists. As a collection of separate studies, this volume is the start and not the end of the possibilities presented by histories of the PSU and how they impacted left culture, thought and practice. Nonetheless, all the contributions presented here are of high quality and, unlike so many compilations of articles, form a very clear and readable whole.

To read this book is to gain any number of insights into the transformation of French politics from the time of DeGaulle into the latter part of the twentieth century. Even when the PSU raised issues they were unable to solve, like the difficult problem of immigrant rights, they pointed to vital concerns that 
needed to be addressed. This skillful work should be read by all those interested in French politics. Moreover, the book implicitly raises a crucial question, all too seldom asked: What do we mean when we say the word "socialism"?

William A. Pelz

Institute of Working Class History (Chicago)

\section{Ralf Hoffrogge, Richard Müller: Der Mann binter der Novemberrevolution (Berlin: Karl Dietz Verlag, 2008).}

Biography has long been a tool used by historians to highlight the nuances of societal change. Of course, this form suffers from the danger that a form of hero worship will lead the scholar into the pitfall of the "great person theory of history." Fortunately, this work avoids this problem while remaining sympathetic to the subject discussed. Hoffrogge has authored a brilliant biography of Richard Müller (1880 - 1943), German radical and author. Although now known only to professional historians, he and his comrades in the Berlín Revolutionary Shop Stewards were important leaders of mass strikes in the years 1916-1918 (9) and later in the events of the German Revolution. After a brief career as a radical workers' leader, Müller left politics and faded into the mists of historical amnesia. With this book, the mists have parted and Müller's significance is again revealed. In addition to his political activism, Müller authored a number of significant works of history such as Vom Kaiserreich zur Republik. (1924). Curiously, the importance of his written works has until now not spared him from historical obscurity.

When discussed at all, the November Revolution is often presented as an event without thought or planning. This does a great disservice to the many unsung radicals like Müller who had laid the groundwork for a workers' revolution. An independent thinker, he began politics in the German Social Democracy (SPD) and later moved into the German Communist Party (KPD). He was never a docile follower of either, opposing the SPD support for World War I and later refusing to join the KPD's early incarnation Spartaksubund because of his fear of ultra-left elements overly enamored with an armed seizure of power (97). Later, he would join the KPD with many of his former comrades only to be politically crushed within a few years by the vicious political infighting and meddling by the Comintern.

Within the Revolutionary Shop Stewards, Müller attempted to develop the strategy of initiating action as union representatives of industrial workers while clandestinely forming an illicit revolutionary organization in response to wartime repression. Although they were key players in the events of 1916-1919, this group has often been overlooked by scholars. Ralf Hoffrogge has authored 